\title{
KRYZYS MIGRACYJNY NA WSCHODNIEJ GRANICY UE - ROLA EUROPOLU WE WSPÓŁPRACY W BEZPIECZEŃSTWIE WEWNĘTRZNYM
}

\author{
MIGRATION CRISIS ON THE EASTERN BORDER \\ OF THE EUROPEAN UNION - EUROPOL'S ROLE IN INTERNAL \\ SECURITY COOPERATION
}

Weronika Jakubczak*

\begin{abstract}
ABSTRAKT
Osiągnięcie wysokiego poziomu bezpieczeństwa wewnętrznego jest jednym z priorytetów Unii Europejskiej. Politykę bezpieczeństwa wewnętrznego UE realizuje, dbając o przestrzeń wolności, bezpieczeństwa i sprawiedliwości. Wobec kryzysu migracyjnego, który trwa już od wielu lat, a obecnie ma nowe oblicze, przed UE pojawiają się nowe wyzwania. UE musi zacieśnić współpracę na wielu poziomach tak, by zapewnić jak najwyższy poziom bezpieczeństwa. Agencje UE wspomagające współpracę w bezpieczeństwie wewnętrznym angażują się $\mathrm{w}$ walkę $\mathrm{z}$ efektami kryzysu migracyjnego i wspierają siły państwowe przy ochronie granic. Rolę jednej z nich -Europolu - oraz działającego w jego ramach Europejskiego Centrum Zwalczania Przemytu Migrantów - EMSC warto poruszyć w aspekcie rozważań nad współpracą $\mathrm{w}$ bezpieczeństwie wewnętrznym. Odpowiedź na kryzys migracyjny musi być bardziej kompleksowa i brać pod uwagę
\end{abstract}

Achieving the high level of internal security is one of the European Union priorities. The EU's internal security policy is realized caring for freedom, safety, and justice. The EU will encounter new challenges resulting from the migration crisis. Although it lasts many years, now it takes a new turn. The EU has to tighten cooperation at many dimensions to ensure the highest level of security. EU agencies support internal security cooperation by engaging into the fight against migration crisis results and enhancing state forces for border protection. In the context of deliberations on cooperation in internal security, it is worth to debate on the role of one of them - Europol, and the European Migrant Smuggling Centre (EMSC) that operates under its auspices. The answer to the migration crisis must be more complex and consider the needs of transit and receiving states, and migrants themselves.

\footnotetext{
* Szkoła Główna Służby Pożarniczej w Warszawie, Instytut Bezpieczeństwa Wewnętrznego.
} 
potrzeby zarówno migrantów, jak i państw przyjmujących czy tranzytowych.

Słowa kluczowe: bezpieczeństwo wewnętrzne; kryzys migracyjny; ochrona granic; Unia Europejska; współpraca międzynarodowa
Keywords: internal security; migration crisis; border protection; European Union; international cooperation

\section{WPROWADZENIE}

Odkąd funkcjonuje nowe oblicze trwającego od 2014 r. kryzysu migracyjnego, kwestie współpracy w bezpieczeństwie wewnętrznym i jej aspektu ochrony granic nabierają nowego znaczenia. Wprowadzenie stanów wyjątkowych na Łotwie i w Polsce oraz nadzwyczajnego na Litwie świadczy o tym, jak istotny jest problem zabezpieczenia kontroli nad przepływem migrantów na wszystkich granicach zewnętrznych UE. Poprzednie fazy kryzysu migracyjnego wykazały słabość UE przy ochronie południowych granic zewnętrznych, głównie na Morzu Śródziemnym, obecnie niestety widzimy podobną tendencję w odniesieniu do granic wschodnich. Coraz większa liczba autorów zgadza się co do tego, że zmiany klimatyczne na pewno przyczynią się do zwiększenia niekontrolowanych ruchów migracyjnych (Intergovernmental Panel on Climate Change, 2014; Vivekananda, 2016).

Dynamiczna sytuacja w Afganistanie po wycofaniu się wojsk amerykańskich i ich sojuszników, działania rządu Rosji (Schmitz, 2021) oraz Białorusi (Komisja Europejska, 2021b), a także trwające już wiele lat problemy w takich krajach jak Pakistan, Iran, Irak czy kraje Afrykańskie wskazują na istnienie dużego prawdopodobieństwa, że sytuacja $\mathrm{z}$ niekontrolowaną migracją nasili się. Coraz częściej słyszy się o wykorzystywaniu tego zjawiska jako elementu wojny hybrydowej. Warto zwrócić uwagę na budzące zaskoczenie wypowiedzi prezydenta Białorusi, który stwierdził, że „na granicy z Polską zaobserwowano 'niebezpieczny trend': podjęto próby przerzucenia broni i amunicję z Donbasu do obozów migrantów, aby sprowokować konflikty między pogranicznikami Białorusi, krajów bałtyckich, Polski i Ukrainy. (...) Dlatego (...) Moskwa i Mińsk muszą wspólnie kontrolować sytuację, by do przerzucania broni nie dochodziło. Jednocześnie Łukaszenko polecił Ministerstwu Obrony, KGB i oddziałom granicznym Białorusi ścisłe kontrolowanie ruchów wojsk NATO i Polski. Wskazał, że przywiozły one na granicę 15 tys. żołnierzy, czołgi, pojazdy opancerzone, śmigłowce i samoloty, choć międzynarodowe umowy zobowiązują do zgłaszania takich 
ruchów" (Rzeczpospolita, 2021). Powyższa wypowiedź jednoznacznie wskazuje na prowadzenie przez tego człowieka polityki dezinformacji, szczególnie że - jak dodał: „Moskwa wysyła nad zachodnie rejony Białorusi strategiczne bombowce do monitorowania sytuacji na granicy z Polską".

Warto - w odniesieniu do politycznego aspektu - podkreślić rozmowy prezydenta Macrona z Putinem (Macron, 2021), a także kanclerz Merkel (Seibert, 2021) z Łukaszenką. Żadna nie była konsultowana $\mathrm{z}$ władzami polskimi, także na szczeblu unijnym - jest to kolejny dowód na to, że w UE brakuje jednego głosu w kwestiach bezpieczeństwa.

Do niefortunnych można zaliczyć rozmowę telefoniczną Angeli Merkel z Łukaszenką, zwłaszcza, że kanclerz Niemiec zakwestionowała ostatnie wybory prezydenckie na Białorusi (Euronews, 2020).

Z punktu widzenia Polski i UE sytuacja na granicach z Białorusią jest dużym zagrożeniem. Ze względu na fakt, że współcześnie obserwowane ruchy migracyjne często mają charakter globalny, gdyż skutki procesów migracyjnych są odczuwane na całym świecie, priorytetem w tym aspekcie powinno być opracowanie rozwiązania optymalnego tak dla migrantów, jak i krajów ich przyjmujących czy krajów, przez których terytorium migranci się przemieszczają. Niekontrolowany napływ migrantów na dużą skalę od 2014 roku na tereny EU, a szczególnie we Włoszech, Grecji, Hiszpanii i na Malcie, stał się przyczyną dużego kryzysu na wielu płaszczyznach, a jego skutki będziemy obserwować latami. Brak efektywności we wprowadzaniu w życie polityki promującej integrację kulturową i społeczną, w takich krajach jak Francja, Belgia, Niemcy czy Holandia, doprowadza do wielu patologii - migranci przybywający z innych kręgów kulturowych nawet $\mathrm{w}$ drugim czy trzecim pokoleniu są często traktowani instrumentalnie i ciężko jest im się odnaleźć jako pełnoprawnym obywatelom państw zachodnich (pomimo tego, że posiadają ich paszporty).

Szczególnie istotne w tym aspekcie jest zaobserwowanie międzynarodowych trendów, które trudno jednoznacznie ocenić. Chodzi o wykorzystywanie migrantów. Przykładem jest postawa Białorusi, wykorzystującej problem migrantów do atakowania Polski i promowania wpływów rosyjskich. UE również jest zdania, że rząd białoruski jest zaangażowany w organizowanie nielegalnego przerzutu migrantów (the orchestration of irregular migration to the EU) (Komisja Europejska, 2021a).

Przy analizowaniu poziomu bezpieczeństwa granic należy wziąć pod uwagę wiele czynników. Faktycznie mieszkańcy i aparat rządzący wewnętrznych państw członkowskich Unii mogą mieć wysoki poziom bezpieczeństwa i czuć się 
bezpiecznie tylko wtedy, gdy granice zewnętrzne skutecznie kontrolują napływ niepożądanych osób, towarów i zagrożeń.

Przy dokonywaniu analizy wpływu migracji na bezpieczeństwo warto wziąć pod uwagę dwa aspekty polityki prowadzonej przez UE w odniesieniu do spraw wewnętrznych: Unijną politykę migracyjną oraz wzmacnianie zewnętrznych granic UE. Jako że wiele kwestii w bezpieczeństwie wewnętrznym dt. migracji i ochrony granic ma związek też $\mathrm{z}$ aspektami unijnej polityki w dziedzinie zwalczania narkotyków, walki z przestępczością zorganizowaną, cyberbezpieczeństwem czy ochroną ludności, trzeba o nich wspomnieć, ale ze względu na ograniczenia edytorskie nie będą one przedmiotem rozważań przedstawionych w niniejszej pracy.

\section{METODOLOGIA}

Główne metody badań wykorzystane przez Autorkę to analiza wyników badań naukowych oraz synteza zastosowana przy opisie kluczowych wniosków wyciągniętych z przeglądu literatury i aktów prawnych. W szczególności skoncentrowano się na dokładnym zbadaniu źródeł informacji opisujących różne aspekty kryzysu migracyjnego, współpracy międzynarodowej w UE odnośnie zaadresowania tego problemu i determinantów bezpieczeństwa granic zewnętrznych itp.

Metody badawcze zastosowane w opracowaniu obejmowały krytyczny przegląd literatury, aktów prawnych oraz analizę porównawczą, a także analizę dostępnych danych internetowych. Jednocześnie przy prowadzeniu badań Autorka skoncentrowała się na wykorzystaniu metody syntezy do wypracowania wniosków i propozycji rozwiązań. Duży wpływ na niniejszą pracę ma użycie analizy koncepcyjnej i krytyki informacji przedstawionych w źródłach.

Analiza jako metoda badawcza pozwoliła Autorce wskazać trend, jaki można zaobserwować przy pojawieniu się konfliktów wynikłych z kryzysu migracyjnego i problemów z ochroną granic.

Co istotne, Autorka zdecydowała się na zastosowanie metody analizy, konstrukcji logicznej i przyczynowo-skutkowej, a także metod uogólniania i abstrakcji, wnioskowania dedukcyjnego i redukcyjnego. Powyższe umożliwiło wskazanie cech powtarzalnych, wyeliminowanie cech nieistotnych oraz znalezienie określonych zależności o problemie badawczym. 


\section{KRYZYS MIGRACYJNY}

Obecnie mamy do czynienia z nową odsłoną kryzysu migracyjnego, w której migranci głównie z krajów Południa starają się przedostać na terytoria krajów Północy.

Migracja jest integralną częścią funkcjonowania organizmów na planecie Ziemia. Do migracji w skali roku jest zmuszone jest 20-25 mln ludzi (Burleson, 2010). Autorzy, którzy starają się oszacować przyszłą skalę tego zjawiska, przypuszczają, że do roku 2050-2100 będzie ono zdecydowanie większe. W szczególności mowa tu o przewidywanej konieczności relokacji, jakiej ma doświadczyć 20\% czy 25\% ludności (Environmental Migration Portal, 2021).

Zgodnie z raportem Europolu „ponad 90\% nielegalnych migrantów, którzy docierają do UE, korzysta z usług przemytników podczas części lub całości swojej podróży. Dwie trzecie z nich nie spełnia kryteriów uzyskania ochrony międzynarodowej i ostatecznie będzie musiało zostać zawrócone. Środki restrykcyjne w kontekście pandemii COVID-19 sprawiły, że przemyt migrantów stał się bardziej złożony, co doprowadziło do większego zaangażowania siatek przestępczych, wyższych cen i ostatecznie wyższych zysków. W pierwszej połowie 2021 r. liczba nielegalnych przejść granicznych wzrosła o 59\% w porównaniu z analogicznym okresem w 2020 r. Oczywiste jest, że przemytnicy migrantów szybko dostosowali się do nowych okoliczności: po początkowym spowolnieniu w marcu i kwietniu 2020 r. działania szybko wznowione" (Europol, 2021c).

W trakcie nielegalnego przerzutu „podstawowe prawa migrantów są często poważnie naruszane, a migranci nie mogą szukać pomocy ze względu na swój nieuregulowany status. Migranci - szczególnie ci w trudnej sytuacji, jak dzieci i małoletni bez opieki - są narażeni na przemoc, wymuszenia, wyzysk, gwałt, maltretowanie, kradzież, porwanie, a nawet zabójstwo” (UNODC, 2018). „Szacunkowo, przestępcze siatki przemytnicze osiągają zyski wysokości 4,7 do 6 mld EUR rocznie na skalę światową" (UNODC, 2018).Ze względu na wiele czynników przewiduje się, że popyt na usługi przemytników będzie się utrzymywał. Oczekuje się, że popyt ten będzie się utrzymywał, napędzany kilkoma czynnikami: wzrostem demograficznym $\mathrm{z}$ towarzyszącymi trudnościami społeczno-gospodarczymi i brakiem możliwości zatrudnienia, dyskryminacją, niestabilnością, konfliktami, degradacją środowiska i zmianą klimatu, postrzeganiem UE jako podmiotu gospodarczego, politycznego, regionu bardziej stabilnego społecznie i ekologicznie; dezinformacja i fałszywa narracja o przemytnikach, zachęcająca migrantów do podejmowania niebezpiecznych podróży z obietnicami, które nie 
pasują do rzeczywistości. Ponadto w perspektywie średnio- i długoterminowej konsekwencje sanitarne, gospodarcze, społeczne i polityczne pandemii mogą zachęcać do nielegalnej migracji do Europy, utrzymując w ten sposób popyt na usługi przemytnicze. W przeszłości kraje szczególnie dotknięte długotrwałym bezrobociem stały się krajami pochodzenia, zarówno w przypadku przemytu migrantów, jak i handlu ludźmi do krajów bardziej zamożnych. Ponadto słabnąca sytuacja gospodarcza w UE może zwiększyć popyt na tanią siłę roboczą na czarnym rynku, co z większym prawdopodobieństwem będzie przyciągać nielegalnych migrantów i prowadzić do wyzysku pracowników, w tym do pracy przymusowej. Do powyższego dochodzi jeszcze aspekt wykorzystywania niekontrolowanych migracji do destabilizacji sytuacji bezpieczeństwa w krajach sąsiednich, z czym obecnie mamy do czynienia w przypadku działań Białorusi wobec Polski.

Kluczową kwestią jest odniesienie się do bieżących problemów i takie rozwinięcie współpracy, tak Europolu i EMSC z krajami członkowskimi, jak i ich kooperacja $z$ agencjami sfery bezpieczeństwa wewnętrznego - przede wszystkim Frontexu, ale i eu-Lisa. Ponadto w szerzej zakrojonych badaniach nad polską perspektywą współpracy w bezpieczeństwie wewnętrznym należy wziąć pod uwagę zaangażowanie innych stron - państw (Niemiec, Francji, Ukrainy, Litwy, Łotwy, Estonii, Wielkiej Brytanii etc.) czy organizacji międzynarodowych innych niż UE: NATO i Grupy Wyszehradzkiej.

\section{BEZPIECZEŃSTWO WEWNĘTRZNE I WSPÓŁPRACA}

Istnieje wiele definicji terminu bezpieczeństwo państwa, np. „taki rzeczywisty stan stabilności wewnętrznej i suwerenności państwa, który odzwierciedla brak lub występowanie jakichkolwiek zagrożeń w sensie zaspokojenia podstawowych potrzeb egzystencjalnych i behawioralnych społeczeństwa oraz traktowania państwa jako suwerennego podmiotu w stosunkach międzynarodowych" (Słownik terminów z zakresu bezpieczeństwa narodowego, 1999).

Definicja bezpieczeństwa wewnętrznego jest dyskutowana przez wielu Autorów. Warto zacząć od rozróżnienia bezpieczeństwa wewnętrznego i zewnętrznego (Cieślarczyk, 2009). Generalnie bezpieczeństwo wewnętrzne oznacza stabilność i harmonijność określonego podmiotu bądź systemu, podmiotu zbiorowego (Symonides, 1984). 
„Bezpieczeństwo państwa jest procesem, co wiąże się z koniecznością jego ciągłego kształtowania, modyfikowania i adaptowania do zmieniających się warunków zewnętrznych i wewnętrznych. Ma on na celu zapobieganie wszelkim zagrożeniom oraz przygotowanie całego społeczeństwa, gospodarki narodowej, terytorium kraju i sił zbrojnych oraz obrony cywilnej do działan w warunkach sytuacji kryzysowych i wojny" (Tyrała, 1999).

Mówiąc o bezpieczeństwie, nie da się uniknąć poruszenia tematyki zagrożeń. Możliwość ich wystąpienia wpływa na poziom bezpieczeństwa w danym kraju. Nawet szybki rozwój technologiczny, obejmujący zbieranie i obrabianie informacji, a także prognostykę, nie pozwala na odpowiednio wczesne przewidzenie wystąpienia zagrożeń globalnych i regionalnych, jak pandemia koronawirusa. Ewolucja systemu bezpieczeństwa była, jest i będzie procesem ciągłym, gdzie ciągle jak najszybsza odpowiedź na zagrożenie będzie dominować nad przewidywaniem.

W odniesieniu do bezpieczeństwa wewnętrznego można stwierdzić, że odnosi się ono do bezpieczeństwa obywateli, instytucji oraz bezpieczeństwa środowiska (Eko Bezpieczeństwa). „Elementami bezpieczeństwa wewnętrznego jest bezpieczeństwo regionalne oraz bezpieczeństwo lokalne. (...) Zapewnienie bezpieczeństwa wewnętrznego wymusza realizację ściśle powiązanych ze sobą (...) funkcji: retrospektywnego i prospektywnego identyfikowania szans i zagrożeń, normowania, instucjonalizacji, działań strategiczno-operacyjnych" (Lisiecki, 2009).

Współpraca w bezpieczeństwie wewnętrznym to taki typ współpracy pomiędzy krajami, ale i organizacjami międzynarodowymi, który ma na celu zwiększenie poziomu tego bezpieczeństwa. $\mathrm{W}$ idealnych warunkach powinna w niej zaistnieć synergia. W dobie globalizacji wszelkiego rodzaju kryzysy w dużo latwiejszy sposób rozprzestrzeniają się na dużą skalę, przyczyną jest powszechny dostęp do internetu i informacji oraz dużo łatwiejsze przemieszczanie się osób. (Jakubczak, 2016). To tłumaczy również, dlaczego współpraca międzynarodowa w bezpieczeństwie ciągle zyskuje na wartości.

UE podejmuje liczne inicjatywy w celu zwiększenia poziomu bezpieczeństwa - odnosi się to tak do sfery regulacji, jak i instytucjonalnej. Wobec kryzysu uchodźczego współpraca w bezpieczeństwie wewnętrznym jest kluczowym elementem zaraz po prowadzeniu działań mających na celu ustabilizowanie sytuacji w rejonach świata, gdzie mają miejsce konflikty i problemy mogące przyczynić się do wzrostu migracji czy zagrożenia terroryzmem. 
Kwestie problemów migracyjnych nie są nowością i są obserwowane i udokumentowane na terenach Europy od początków cywilizacji (Jakubczak, 2016b). Parcie cywilizacyjne jest obserwowane od tysięcy lat i zdarzały się bardzo długie okresy, kiedy znaczna część Europy była pod władaniem arabskim (Marin-Guzman, 1992; Morris, 2003).

Czy możliwe jest wypracowanie realnie działającego rozwiązania, jeśli chodzi o bezpieczeństwo granic UE? Brak jest jednoznacznej odpowiedzi. Współpraca w bezpieczeństwie wewnętrznym jest na pewno dobrą drogą, jednocześnie, mając na uwadze skomplikowany charakter ruchów migracyjnych i bardzo duże ryzyko zwiększenia się ich, rozwiązanie powinno być systemowe. Zaangażowanie Zachodu w Afganistanie doskonale zostało ocenione jednym zdaniem przez Generała Marka Milleya, doradcę prezydenta USA „To był sukces logistyczny, ale strategiczna porażka” (Committee on Armed Services, US Senate, 2021).

Obecna sytuacja pokazuje, że bez zaadresowania problemu korupcji i wypracowania kompleksowego podejścia do potrzeb ludności, prowadzenie misji pokojowych nie sprawdza się. Skoro jesteśmy w stanie rozpowszechnić konsumpcjonizm i koncentrować się na niekontrolowanym wzroście, zmiana paradygmatów na zrównoważoną produkcję i konsumpcję oraz rezygnacja z rywalizacji i pogoni za wzrostem gospodarczym mogłaby osiągnąć długookresowo sukces. Rozwiązaniem powinno być wprowadzenie regulacji, które zapobiegną negatywnym efektom procesów globalizacji i dalszemu zwiększaniu się różnic pomiędzy najbogatszymi a najbiedniejszymi. Warto byłoby zrezygnować z obsesyjnego zafiksowania się na rywalizacji i przymusie osiągania wzrostu gospodarczego. Znany krytyk konsumpcjonizmu i wzrostu ekonomicznego Smil, stwierdził: „możemy tylko spekulować, kiedy i jak możemy położyć kres wzrostowi materialnemu i stworzyć nowe społeczeństwo, które przetrwałoby bez czczenia niemożliwego boga stale rosnącej konsumpcji: żaden kraj nie zobowiązał się do podążania taką ścieżką" (Smil, 2019).

Ze względu na ograniczoną objętość niniejszej pracy kwestie te zostaną poruszone szerzej w kolejnych publikacjach Autorki. Natomiast dla potrzeb niniejszego opracowania w dalszej części zostaną omówione aspekty takie jak: działania Europolu oraz Europejskiego Centrum Zwalczania Przemytu Migrantów. 


\section{EUROPOL}

Europol jest jedną z kluczowych agencji UE odpowiedzialnych za wybrany aspekt bezpieczeństwa wewnętrznego UE. W ramach swojego mandatu wspiera ona 27 państw członkowskich w zwalczaniu poważnej przestępczości międzynarodowej i terroryzmu. Charakteryzuje się prowadzeniem szerokiej współpracy z wieloma państwami partnerskimi (innymi niż członkowie UE) oraz organizacjami międzynarodowymi.

Ostatnio, co coraz częściej jest podkreślane przez ekspertów, polityków i prasę, w odniesieniu do kryzysu migracyjnego zaczyna się zauważać aspekt przestępczości zorganizowanej, która za nim stoi. Wcześniej retoryka kładła nacisk na konieczność przyjmowania wszystkich migrantów, bo są to potencjalnie potrzebujący pomocy uchodźcy. Jakkolwiek nastąpiło to po długim okresie doświadczeń i walki ze skutkami nieuregulowanych migracji. Rozbudowano organizacje o charakterze przestępczym i terrorystycznym, które generują poważne zagrożenia na szczeblu strategicznym dla bezpieczeństwa wewnętrznego UE oraz na poziomie bezpieczeństwa obywateli. W odniesieniu do powyższego, zgodnie z informacjami o Europolu, największymi zagrożeniami dla bezpieczeństwa są: terroryzm, międzynarodowy nielegalny obrót środkami odurzającymi i pranie pieniędzy, zorganizowane oszustwa, fałszowanie euro, przemyt ludzi (Europol, 2021).

Zdecydowanie zaobserwować można też rozwój nowego typu zagrożeń, jak cyberprzestępczość i handel ludźmi. W szczególności kwestie związane z cyberzagrożeniami zyskują na znaczeniu. Spowodowane jest to faktem, że pandemia COVID-19 wymusiła przeniesienie na dużą skalę wielu rodzajów działalności do internetu. Tyczy się to również infrastruktury krytycznej, co zwiększyło jej ekspozycję na cyberataki. Warto również wspomnieć, w odniesieniu do zagrożenia związanego z niekontrolowanymi migracjami, że werbunek ludzi przez przemytników coraz częściej odbywa się przy pomocy mediów społecznościowych. Przestępcy powodowani chęcią zysku bardzo szybko wprowadzają stosowanie nowych technologii, co daje im szansę na zdobycie przewagi wobec organów ścigania działających tradycyjnymi metodami i zgodnie z prawem. Celem przekazywania partnerom kompleksowych informacji o przestępstwach Europol zapewnia unikalne usługi, np. sporządzając regularne oceny zawierające złożone, perspektywiczne analizy przestępczości i terroryzmu.

Wykonując swój mandat, Europol odpowiada za wspomaganie organów ścigania w UE w przy zwalczania przestępczości i terroryzmu we wszystkich 
obszarach swoich uprawnień. Instytucja ta prowadzi działania operacyjne w wielu obszarach.

Istnieje rozbudowana współpraca na poziomie samych agencji. Warto podkreślić, że „widoczny wzrost wkładu Frontexu w zwalczanie przestępczości na zewnętrznych granicach UE stworzył okazję do lepszego wykorzystania zdolności wywiadowczych i policyjnych Frontexu oraz stworzył podstawę do bliższej współpracy z Europolem i unijnym wymiarem sprawiedliwości i sprawami wewnętrznymi (WSiSW)" (Zarychta-Romanowska, 2021).

W strukturze organizacyjnej Europolu działa Europejskie Centrum Zwalczania Przemytu Migrantów - EMSC: instytucja koncentrująca się na aktywnym wspieraniu krajów UE przy rozpracowywaniu i niszczeniu siatek przestępczych odpowiedzialnych za zorganizowany przemyt nielegalnych migrantów. EMSC monitoruje na bieżąco, jakie pojawiają się punkty zapalne, i wzmacnia zdolności unijne do zwalczania siatek przemytu ludzi (Europol, 2021a). EMSC powstało na początku 2016 r. po okresie bardzo dynamicznej nielegalnej migracji w rejonie Morza Śródziemnego, kiedy Europol ustalił, że wielu migrantów płaciło organizacjom przestępczym za podróż do UE, szczególnie drogą morską (Komisja Europejska, 2021d).

Zaadresowanie problemu funkcjonowania tego, generującego przemytnikom co roku wielomiliardowe zyski, sektora przestępczości stało się zasadniczą częścią unijnej reakcji na kryzys migracyjny. Migranci ryzykują często życiem, kraj przyjmujący też może ryzykować zmniejszeniem poziomu bezpieczeństwa. W agendzie UE w sprawie migracji (2015) określono, że walka z przemytem migrantów jest kluczowym priorytetem (Komisja Europejska, 2015c).

EMSC koncentruje się na wspieraniu Policji i Straży Granicznej. Odpowiada za koordynację wysoce złożonych transgranicznych operacji antyprzemytniczych. Należy nadmienić, że EMSC ściśle współpracuje z partnerskimi agencjami UE - współpracy sądowej (Eurojust) i zarządzania granicami Frontex.

Wobec obecnej fazy kryzysu migracyjnego, dotykającego Polskę, EMSC udostępni pomoc swoich ekspertów. Jest to spowodowane szczególną sytuacją na granicy z Białorusią i skandaliczną anty-humanitarną postawą przedstawicieli reżimu Łukaszenki oraz brakiem poszanowania prawa międzynarodowego, tak wobec migrantów, jak i Polski.

Tragiczna sytuacja na polskiej granicy jest szansą, by przedstawiciele UE wykazali, jak działa współpraca w bezpieczeństwie wewnętrznym. Niestety, „dotychczasowe nieefektywne reakcje służb unijnych na zagrożenia i kryzysy migracyjne ostatnich lat powodują coraz silniej odczuwalny społeczny brak 
poczucia bezpieczeństwa obywateli UE, tym samym dających przyzwolenie na proces ograniczania ich własnego, pełnego korzystania $\mathrm{z}$ podstawowych praw i wolności Europejczyków, w rezultacie prowadząc do głębokiego kryzysu instytucjalnego i politycznego. Jego przejawem jest utrata zaufania do rządów i organów unijnych odpowiedzialnych za utrzymywanie bezpieczeństwa i porządku publicznego, a tym samym idei europejskich, czego skutkiem jest chociażby wzrost popularności ruchów narodowo-ksenofobiczno-populistycznych" (Szostak, 2020).

Odpowiednią rekomendacją będzie wypracowanie kompleksowej współpracy, „(...) zwłaszcza w zakresie kooperacji europejskich instytucji wymiaru sprawiedliwości, migracji i spraw wewnętrznych, w rezultacie może zapewnić renesans społeczeństwa UE i idei podstawowych wolności, przy jednoczesnym stworzeniu korzystnego klimatu gospodarczego" (Szostak, 2020).

\section{PODSUMOWANIE}

Ze względu na fakt, że nie jest możliwe odniesienie się do potrzeb wszystkich ludzi, którzy chciałby zmienić miejsce życia, bo ich populacja jest liczna - 82,4 mln migrantów, w tym 26,4 mln uchodźców - (UNHCR, 2020), konieczne jest głębsze przeanalizowanie tematyki i przygotowanie kompleksowego programu zmiany polityki prowadzonej wobec uchodźców, a raczej rządów państw, skąd te osoby pochodzą, oraz także wypracowanie skutecznej metody walki z siatkami przerzutu migrantów (UNIC Warsaw, 2020).

Biorąc pod uwagę ważniejsze zagrożenia, niemożliwe jest prowadzenie obecnej polityki nakierowanej na kontrolę osób i utrzymywanie ich w ubóstwie i zależności, w celu zmaksymalizowania zysku ponadnarodowych korporacji.

Wobec postępującej globalizacji i zmian klimatycznych, zwiększa się skala zagrożenia niekontrolowanymi migracjami. Powyższe wymaga zmiany we współpracy w bezpieczeństwie wewnętrznym - dla UE najważniejsze jest wspieranie kooperacji przy ochronie granic zewnętrznych.

Aspekty te są kluczowe dla wszystkich państw unijnych, gdyż nawet jeśli migranci dostają się na terytorium EU poprzez granice greckie, włoskie czy polskie, to i tak dążą oni docelowo do osiedlenia się w Szwecji czy Niemczech.

Ze względu na różnice kulturowe i problemy, z jakimi borykają się kraje (Francja, Belgia, Niemcy, Szwecja) z liczną populacją osób, które przybyły do UE $\mathrm{z}$ innego kręgu kulturowego, warto przygotować kompleksowy program, który 
umożliwiłby integracje migrantów. Obecnie brakuje takiego podejścia i rodzi to poważne problemy, tak dla migrantów, jak i dla europejskich społeczeństw.

Po pierwsze trzeba zapewnić odpowiedni sposób zabezpieczenia granic, tak by migranci nie mogli się przedostać na terytorium EU poza kontrolą należy stosować wszelkiego rodzaju ochronę fizyczną i najnowsze technologie. W ten sposób UE może odpowiednio zaadresować potrzeby migrantów i w zdecydowany sposób uniknąć przenikania na jej tereny terrorystów i przestępców. Po drugie należy przygotować odpowiednie ośrodki dla migrantów, którzy mogą przebywać na terytorium UE. Należy odpowiednio zaadresować aspekty związane $\mathrm{z}$ traumą, którą przeżyli. Krótkoterminowe narzędzia pracy ze strukturami podkorowymi, jak EMDR czy Brainspotting (Grey, 2013), są bardzo skuteczne przy pracy z PTSD. Pozwalają one na szybkie przepracowanie traumatycznych doznań. Dodatkowym argumentem jest, że w przeciwieństwie do wielu rodzajów terapii pozwalają one na uniknięcie retraumatyzacji. Ze względu na fakt, że nie jest konieczne używanie ośrodków mowy podczas prowadzenia sesji EMDR czy brainspottingu, przyczyni się to do optymalizacji kosztów i większego dostępu do tego typu technik w porównaniu do terapii (Van Der Kolk, 1994; Van Der Kolk, 2001).

W ośrodkach powinno też prowadzić się odpowiednie kursy dotyczące integracji i szacunku dla kultury państwa i populacji, gdzie migranci mają nadzieję na dalsze życie. Nawet jeśli ich pobyt miałby być czasowy, konieczne jest wyedukowanie ich, by mogli zrozumieć, jak funkcjonuje lokalne społeczeństwo i że kluczowe jest dostosowanie się do zasad tam obowiązujących. Jednocześnie migranci powinni mieć możliwość pielęgnowania swojej kultury, o ile nie jest to sprzeczne z zasadami lokalnymi. Tu pojawia się często konflikt interesów - toteż raz jeszcze warto zdecydowanie podkreślić, że migranci powinni znajdować schronienie w krajach podobnych kulturowo - będzie to mniejszy stres tak dla nich, jak i dla obywateli kraju przyjmującego.

Istotne jest też zapewnienie pracy i przeszkolenia migrantów, tak by pojawiła się obopólna korzyść. Migranci z doświadczeniami traumatycznymi powinni uzyskać pomoc specjalisty i dostęp do narządzi, jak brainspotting czy EMDR (Shapiro, 1989), oraz pracę pozwalającą odzyskać sprawczość i kontrolę na własnym życiem.

W związku z faktem, że współpraca w bezpieczeństwie wewnętrznym w UE w odniesieniu do kryzysu migracyjnego - ochrony granic powinna - być rozwijana w sposób ustrukturyzowany, ważne jest przeprowadzenie wspólnej szerokiej kampanii informacyjnej w miejscach, skąd pochodzą migranci. Mogą 
oni docierać do UE poprzez znane już szlaki, ale problem dotyczy wszystkich państw członkowskich i kluczowe jest zaangażowanie każdego z nich. Migranci powinni zdawać sobie sprawę z tego, że opuszczając swoje kraje, będą musieli dokonać zmian w swoich przekonaniach. Nie jest możliwe dokonanie prawdziwie głębokiej transformacji, jeśli nie zmienia się swoich poglądów. Człowiek, który zmienia miejsce pobytu, ale oczekuje, że przenosząc swoje obyczaje i sposób działania $\mathrm{z}$ miejsca, gdzie ma miejsce konflikt bądź gdzie panuje bieda i brak jest rządów prawa, musi zostać przystosowany do rzeczywistości, w której panuje większa stabilność. Nie można oczekiwać, że taka zmiana nastąpi samodzielnie. Przykładem są emigranci, którzy żyją w enklawach i nie chcą/nie mogą się integrować; miejsca, gdzie zamieszkują są miniaturami miejsc, z których przybyli - nie panuje tam demokracja, kobiety nie mają pełni praw, często panuje nieład, a służby kraju przyjmującego tracą kontrolę nad takim obszarem. Mamy do czynienia z paradoksalną sytuacją - ludzie, który zdecydowali się opuścić swoje kraje, bo nie odpowiadał im reżim i problemy przez niego generowane, nie rozumieją, że tak reżim, jak i problemy, mają związek z ich własnymi przekonaniami, którymi się kierują na co dzień. Ucieczka od reżimu powinna być też szansą na zmianę przekonań. Niestety, często po przybyciu na nowe miejsce migranci zaczynają odtwarzać styl życia i zasady, przed którymi chcieli uciec. Z drugiej strony konieczne jest edukowanie społeczeństw krajów przyjmujących, że należy kategorycznie zwalczać przejawy wrogich zachowań ze strony przybyszów przy pomocy służb, a media powinny prowadzić rzetelną kampanię informacyjną dt. konsekwencji braku poszanowania prawa. Żadne przejawy przemocy typu: okaleczanie rytualne dzieci, przemoc wobec kobiet, brak poszanowania dla prawa kultury kraju przyjmującego, nie powinny być tolerowane.

Taka polityka pomoże ukrócić handel ludźmi oraz przemyt nielegalnych emigrantów. Wypracowanie tego typu rozwiązań znajdziemy w dokumencie A renewed EU action plan against migrant smuggling (2021-2025) (Komisja Europejska, (2021a). Konieczna jest natychmiastowa faktyczna implementacja jego zapisów.

Warto też nadmienić, że przy rozważaniach dotyczących pomoc migrantom powinny być brane pod uwagę głębsze rozważania na temat korelacji pomiędzy pewnego typu uwarunkowaniami, jak np. poszanowanie praw kobiet, tolerancja dla odmienności, ale i dla przemocy wobec słabszych, o czym pisze od lat w swoich pracach prof. Andreu Ginestet (Ginestet Menke, 2017).

Niestety w odniesieniu do współpracy w bezpieczeństwie wewnętrznym w sprawie kryzysu migracyjnego Unia Europejska nie wykazała się skutecznością 
i samodzielnością zastosowanych instrumentów i dopiero nawiązanie współpracy z Turcją i przekazanie jej kwoty na rzecz zaadresowania problemu migracyjnego przyniosło korzyść, jeśli chodzi o zmniejszenie fali migrantów (van Heukelingen, 2021). Należy jednak zauważyć, że powyższe działanie nie przyczyniło się do całkowitego zatrzymania niekontrolowanego napływu migrantów.

Niestety na przykładzie tak obecnych, jak i wcześniejszych doświadczeń w odniesieniu do współpracy w bezpieczeństwie wewnętrznym, jak i w odniesieniu do walki z kryzysem migracyjnym oraz jego skutkami okazuje się, że istnieje bardzo duże pole do usprawnień. Obywatele UE cierpią na uzasadniony „brak poczucia bezpieczeństwa i utratę zaufania do organów władzy”. Współpraca ze strony Europolu niestety nie jest w stanie znacząco zmienić powyższego.

Odpowiednią rekomendacją jest podkreślenie, że obecny stan regulacji prawnych i braku podejmowana zdecydowanych kroków może doprowadzić do tragedii. Granice to obszar, gdzie bezpieczeństwo wewnętrze jest ściśle związane z bezpieczeństwem międzynarodowym. Unia, ograniczając się do deklaracji o zwiększaniu swojej roli na arenie globalnej, jednocześnie nie potrafi zadbać ani o swoje terytorium (nieregularne migracje - Polska obecnie, Hiszpania, Grecja, Włochy od minimum 2014 r., cyberataki Polska 2021, Estonia 2008), ani okolice (Ukraina 2014, Gruzja 2008, Libya i Syria 2011). Szansą na polepszenie sytuacji jest wypracowanie lepszej kompleksowej współpracy.

\section{BibliografiA:}

Burleson, E. (2010). Climate change displacement to refuge. J. Envtl. L. \& Litig.

Cieślarczyk, M. (2009). Teoretyczne i metodologiczne podstawy badania problemów bezpieczeństwa i obronności Państwa. Siedlce: Wydawnictwo Akademii Podlaskiej.

Committee on Armed Services, US Senate (2021) Hearing to receive testimony on the conclusion of military operations in afghanistan and plans for future counterterrorism operations, Tuesday, September 28, 2021. Pobrane z: https://www.armed-services. senate.gov/imo/media/doc/21-73_09-28-2021.pdf.

Environmental Migration Portal, (2021). Knowledge Platform on People on the Move in a Changing Climate. Pobrane $\mathrm{z}$ : https://knowledge.unccd.int/kss/environmentalmigration-portal-knowledge-platform-people-move-changing-climate.

Euronews, (2020). EU announces sanctions against Belarus over, violence' on protesters and electoral 'falsification', https://www.euronews.com/2020/08/14/eu-announcessanctions-against-belarus-over-violence-on-protesters-and-electoral-falsifica.

Europol, (2021a). European Migrant Smuggling Centre - EMSC. Pobrane z: https:// www.europol.europa.eu/about-europol/european-migrant-smuggling-centre-emsc.

Europol, (2021b). Informacje o Europolu. Pobrane z: https://www.europol.europa.eu/ pl/about-europol. 
Europol, (2021c). European Migrant Smuggling Centre, $5^{\text {th }}$ Annual Report - 2021.

Ginestet, Menke, A. M., (2017). General System Theory of Violence. Scaling human Complexity. Proposal to scale complexity containing: 1 Single necessary complexity paradigm "lethal and vital complexity". Wuppertal: COBAWU Institute.

Grey, D. (2013). Brainspotting: The Revolutionary New Therapy for Rapid and Effective Change. Louisville: Sounds True Inc.

Jakubczak, W., (2016a). Condition of Cybersecurity in Poland - Selected Aspects. Przedsiębiorczość i Zarządzanie, 17(5.1).

Jakubczak, R., Jakubczak, W. (2016b). Azjatyckie parcie cywilizacyjne na Europe. W: S. Jaczyński, J. Kunikowski (red.). Kultura Bezpieczeństwa. Potrzeby i Uwarunkowania (s. 209-248). Siedlce: Uniwersytet Przyrodniczo-Humanistyczny.

Komisja Europejska, (2021a) A renewed EU action plan against migrant smuggling (2021-2025) - COM(2021) 591, Pobrane z: https://ec.europa.eu/home-affairs/ renewed-eu-action-plan-against-migrant-smuggling-2021-2025-com-2021-591_en. Komisja Europejska 2, Commission proposes partial suspension of EU-Belarus Visa Facilitation Agreement for officials of the Belarus regime. Pobrane $\mathrm{z}$ : https://ec.europa. eu/commission/presscorner/detail/en/IP_21_4906.

Komisja Europejska 3, Komunikat Komisji Do Parlamentu Europejskiego, Rady, Europejskiego Komitetu Ekonomiczno-Społecznego i Komitetu Regionów Europejski Program w Zakresie Migracji, COM(2015) 240 final. Pobrane z: https://eur-lex.europa.eu/ legal-content/PL/TXT/PDF/?uri=CELEX:52015DC0240\&from=HU, 2015.

Komisja Europejska 4, Migration and Home Affairs, European Migrant Smuggling Centre - EMSC, Migrant Smuggling, Pobrane z: https://ec.europa.eu/home-affairs/policies/ migration-and-asylum/irregular-migration-and-return/migrant-smuggling_en, 2021.

Lisiecki, M., (2009). Jakość w zarządzaniu bezpieczeństwem wewnętrznym. W: M. Lisiecki, M. Raczkowska-Lipińska, B. Sitek, W. Pokruszyński (red.). Bezpieczeństwo wewnętrzne Rzeczypospolitej Polskiej na tle innych państw Unii Europejskiej Stan obecny oraz perspektywy zmian. Józefów-Szczytno: Wyższa Szkoła Gospodarki Euroregionalnej im. Alcide De Gasperi, Wyższa Szkoła Policji.

Intergovernmental Panel on Climate Change (IPCC) (2014). Climate Change 2014: Impacts, Adaptation and Vulnerability, IPCC/Cambridge University Press: Cambridge/New York.

Macron, E. (2021). Entretien téléphonique avec M. Vladimir Poutine, Président de la Fédération de Russie. Pobrane z: https://www.elysee.fr/emmanuel-macron /2021/11/15/entretien-telephonique-avec-m-vladimir-poutine-president-de-lafederation-de-russie-1.

Marin-Guzman, R. (1992). Crusade in Al-Andalus: The Eleventh Century Formation of the Reconquista as an Ideology. Islamic Studies, 31(3), 287.

Morris, T.A. (2003). Europe and England in the Sixteenth Century. Routledge.

Rzeczpospolita (2021). Łukaszenko: Broń z Donbasu przerzucana do obozów migrantów. Pobrane z: https://www.rp.pl/polityka/art19095561-lukaszenko-bronz-donbasu-przerzucana-do-obozow-migrantow. 
Schmitz, R. (2021). The EU accuses Belarus of luring global migrants into other European countries. Pobrane z: https://www.npr.org/2021/10/12/1045345417/poland-belarus-lukashenko-eu-migrants-asylum?t=1634537139051.

Seibert, S. (2020). Bundeskanzlerin Merkel telefoniert mit Herrn Alexander Lukaschenko. Pobrane z: https://www.bundesregierung.de/breg-de/suche/bundeskanzlerinmerkel-telefoniert-mit-herrn-alexander-lukaschenko-1981624.

Shapiro, F. (1989). Eye movement desensitization:a new treatment for post-traumatic stress disorder. Journal of Behavioral Therapy Exp. Psychiatry, 20, 211-217.

Słownik terminów z zakresu bezpieczeństwa narodowego (1999). Warszawa: AON.

Smil, V. (2019). Growth: From Microorganisms to Megacities. Cambridge, MA: MIT Press.

Symonides, J. (1984). Problemy pokoju i bezpieczeństwa międzynarodowego we wspótczesnym świecie. Wrocław: Ossolineum.

Szostak, M., Zarychta-Romanowska, K. (2020). Policyjne strategie bezpieczeństwa granic Unii Europejskiej. Postulaty de lege lata i de lege ferenda. Przeglad Prawa $i$ Administracji, $\operatorname{CXX}(1 / 2)$, Wrocław.

Tyrała, P. (1999). Edukacja dla ochrony cywilnej. Organizacja i zarzadzanie systemem. Rzeszów: Fosze.

UNHCR, (2020). Global Trends in Forced Displacement. Pobrane z: https://www.unhcr. org/60b638e37/unhcr-global-trends-2020.

UNIC Warsaw (2020). Handel ludźmi i przemyt migrantów - wykorzystywanie ludzi szukających lepszego życia. Pobrane z: http://www.unic.un.org.pl/przestepczosc/ handel.php.

UNODC (2018). Global study on smuggling of migrants.

Van Der Kolk, B.A. (1994). The body keeps the score: memory and the evolving psychobiology of post- traumatic stress. Harvard Review of Psychiatry, 1, 253-265. DOI: 10.3109/10673229409017088.

Van Der Kolk, B.A., Hopper, J.W., Osterman, J. E. (2001). Exploring the nature of traumatic memory: combining clinical knowledge with laboratory methods. Journal of Aggresssion, Maltreatment and Trauma, 4, 9-31.

van Heukelingen, N. (2021). A new momentum for EU-Turkey Policy Brief cooperation on migration, Clingendael Policy Brief, Netherlands Institute of International Relations Clingendael.

Visegrad Group (2021). Europol to assist Poland in Belarus border crisis. Pobrane z: https://www.visegradgroup.eu/news/europol-to-assist-poland.

Vivekananda, J., Rüttinger, L. (2016). Understanding the compound risks of climate change and fragility, SIPRI Yearbook.

Zarychta-Romanowska, K., Boćko, J., Mierzwa, J. (2021). Border intelligence cooperation in the time of Covid 19- omnifarious dimensions of EU Security strategies. The Journal of European and American Intelligence Studies, 4(3). 